\title{
Pengelompokan Buah Jeruk menggunakan Nä̈ve Bayes dan Gray Level Co-occurrence Matrix
}

\author{
Abdul Rahmat Karim Haba ${ }^{\text {a,1,* }}$ dan Kartika Chandra Pelangi a,2 \\ ${ }^{a}$ Universitas Ichsan Gorontalo, Jln. Achmad Najamuddin, Kota Gorontalo dan Kode Pos 96115, Indonesia \\ Irkarimhaba@gmail.com; ${ }^{2}$ apelagie@gmail.com \\ * corresponding author
}

\begin{tabular}{|c|c|}
\hline INFORMASI ARTIKEL & ABSTRAK \\
\hline $\begin{array}{l}\text { Dikirim: } 23 \text { Desember } 2019 \\
\text { Diulas: } 12 \text { Februari } 2020 \\
\text { Direvisi: } 13 \text { April } 2020 \\
\text { Diterbitkan: } 27 \text { April } 2020 \\
\text { Kata Kunci: } \\
\text { Klasifikasi } \\
\text { GLCM } \\
\text { Naïve Bayes }\end{array}$ & $\begin{array}{l}\text { Buah jeruk keprok adalah buah yang kaya akan kandungan vitamin C yang } \\
\text { tinggi. Setiap pemilik kebun buah selalu berusaha meningkatkan kualitas } \\
\text { perkebunan mereka. Dalam pemilihan buah jeruk keprok untuk } \\
\text { dikelompokkan yang matang atau yang belum matang pada masa panen } \\
\text { biasanya patani kebun selama ini sudah terbiasa, akan tetapi petani kebun } \\
\text { terkadang dalam mengelompokkan buah jeruk yang matang mendapatkan } \\
\text { permasalahan seperti terbatasnya fisik petani kebun yang dalm hal ini } \\
\text { disebabkan oleh fakor kelelahan karena masih melakukan pengelompokkan } \\
\text { dengan sistem konvensional sehingga tidak efektif dan efisien dalam } \\
\text { mengelompokan buah jeruk yang matang. Maka dari pada itu diperlukan } \\
\text { sebuah sistem komputerisasi yang dapat membantu petani kebun dalam } \\
\text { mengelompokkan buah jeruk yang matang. Salah satu teknologi yang } \\
\text { berkembang saat ini dalam bidang pertanian dan perkebunan adalah dengan } \\
\text { pengolahan citra digital menggunakan sistem klasifikasi dengan berdasarkan } \\
\text { tekstur dan metode nä̈ve bayes. Berdasarkan hasil yang telah dilakukan, } \\
\text { bahwa dengan sistem klasifikasi menggunakan metode Nä̈ve Bayes pada } \\
\text { citra jeruk keprok dapat diklasifikasikan dan memperoleh kinerja yang } \\
\text { efektif dan efisien berdasarkan pengujian sebesar } 82 \% \text { sehingga dapat di } \\
\text { implementasikan. }\end{array}$ \\
\hline \multirow[t]{2}{*}{$\begin{array}{l}\text { Keywords: } \\
\text { Classification } \\
\text { GLCM } \\
\text { Naïve Bayes }\end{array}$} & $\begin{array}{l}\text { ABSTRACT } \\
\text { Tangerines are fruits that are rich in high vitamin C content. Every orchard } \\
\text { owner always tries to improve the quality of their plantation. In the selection } \\
\text { of tangerines to be classified as ripe or immature at harvest time, the garden } \\
\text { planters are already accustomed, but sometimes the farmer grouping the ripe } \\
\text { oranges has problems such as physical limitations of the farmer, which is } \\
\text { caused by fatigue factor. because it is still grouping with conventional } \\
\text { systems so it is not effective and efficient in classifying ripe oranges. So } \\
\text { from that we need a computerized system that can help gardeners in } \\
\text { classifying ripe oranges. One of the technologies currently developing in } \\
\text { agriculture and plantations is digital image processing using a classification } \\
\text { system based on the texture and naive bayes method. Based on the results } \\
\text { that have been made, that the classification system using the Naïve Bayes } \\
\text { method on tangerine images can be classified and obtain effective and } \\
\text { efficient performance based on testing of } 82 \% \text { so that it can be implemented. }\end{array}$ \\
\hline & This is an open access article under the $\mathrm{CC}-\mathrm{BY}-\mathrm{SA}$ license. \\
\hline
\end{tabular}

\section{Pendahuluan}

Jeruk keprok memiliki nama latin Citrus reticulata. Jeruk ini cocok untuk ditanam di daerah yang memiliki ketinggian antara 500-1.200 meter di atas permukaan laut yang memiliki musim kering cukup panjang. Buah jeruk keprok adalah buah yang kaya akan kandungan vitamin C yang tinggi. Selain itu buah jeruk keprok ini manis juga mempunyai rasa yang menyegarkan serta banyak masyarkat yang mengkonsumsinya[1].

Salah satu faktor dalam menentukan buah jeruk keprok yang telah matang dapat dilihat dari tekstur kulit buah jeruk keprok. Pada tekstur yang dimaksudkan berupa textur yang halus, tipis serta mengkilat. Dalam pemilihan buah jeruk keprok untuk dikelompokkan yang matang atau yang belum matang pada masa panen biasanya patani kebun selama ini sudah terbiasa, akan tetapi petani kebun terkadang dalam mengelompokkan buah jeruk yang matang mendapatkan permasalahan seperti terbatasnya fisik petani kebun yang dalm hal ini 
disebabkan oleh fakor kelelahan karena masih melakukan pengelompokkan dengan sistem konvensional sehingga tidak efektif dan efisien dalam mengelompokan buah jeruk yang matang. Maka dari pada itu diperlukan sebuah sistem komputerisasi yang dapat membantu petani kebun dalam mengelompokkan buah jeruk yang matang. Tujuan dari penelitian ini adalah Untuk melakukan pengelompokkan pada kematangan buah jeruk keprok dan untuk memperoleh sistem dalam mengelompokkan buah jeruk yang efektif dan efisien sehingga dapat di implementasikan. Salah satu teknologi yang berkembang saat ini dalam bidang pertanian dan perkebunan adalah pengolahan citra digital.

Pengolahan citra digital merupakan bagian dari perkembangan teknologi yang menginginkan agar mesin (komputer) dapat mengenali citra seperti layaknya penglihatan manusia[2]. Selain itu juga Pengolahan citra digital adalah teknik mengolah citra yang bertujuan memperbaiki kualitas citra agar mudah diinterpretasi oleh manusia atau mesin komputer yang dapat berupa foto maupun gambar bergerak. Pengolahan citra digital memiliki beberapa kelebihan, yaitu murah, cepat, dan tidak merusak sampai yang diukur dan mampu mengidentifikasi fisik produk secara obyektif[3]. Citra sendiri merupakan istilah lain untuk gambar sebagai salah satu komponen multimedia yang memegang peranan yang sangat penting sebagai bentuk informasi visual. Citra mempunyai karakteristik yang tidak dimiliki oleh data teks, yaitu citra kaya dengan informasi[4]. Citra disini merupakan matrik dua dimensi dari fungsi intensitas cahaya,karena itu referensi citra menggunakan dua variabelyang menunjuk posisi pada bidang dengan sebuah fungsi intensitas cahaya[5].

Pengelompokkan atau klasifikasi jenis buah merupakan pekerjaan yang membutuhkan waktu dan pengetahuan. Perkembangan visi komputer memungkinkan otomatisasi klasifikasi jenis buah dengan efisien dan akurat. Selain fitur ekstraksi GLCM yang digunakan dalam mengenali jenis buah, pemilihan teknik klasifikasi yang sesuai juga merupakan faktor yang dapat mempengaruhi keberhasilan pengenalan untuk klasifikasi jenis buah[6].

Penelitian dalam bidang pengolahan citra terkait metode Naive Bayes telah pernah dilakukan oleh beberapa peneliti sebelumnya. Diantaranya adalah peneliti atas nama Antonio Ciputra, Ekstraksi fitur yang digunakan pada penelitian ini rerata intensitas, energi, entropy, standar deviasi, smothness dan skewness. Keenam fitur tersebut diklasifikasi dengan naive bayes. Data yang digunakan pada penelittian ini adalah 130 citra, yang terdiri dari 100 citra latih dan 30 citra uji. Hasil akurasi metode ini mencapai 63\%[7]. Penelitian atas nama rosa andrie asmara dengan hasil proses klasifikasi jenis kelamin dengan metode Naive Bayes yang menghasilkan akurasi kecocokan sebesar 80\%[8]. Penelitian atas nama I Gede Surya Rahayuda, dari percobaan yang dilakukan didapatkan bahwa tingkat akurasi yang dihasilkan cukup tinggi, terdapat 3 buah kategori jenis obat yang memiliki akurasi yang tinggi yaitu pada jenis Obat Bebas, Obat Bebas Terbatas dan Obat Keras[9]. Penelitian atas nama Rizky Ayomi Syifa, Penelitian ini menghasilkan tingkat akurasi sebesar $71,42 \%$ untuk ekstraksi ciri metode transformasi wavelet pasangan kombinasi koefisien aproksimasikoefisien detail vertikal dan akurasi pada metode GLCM sebesar 80\% untuk kombinasi homogenitaskorelasi[10]. Fuzy Yustika Manik, Hasil klasifikasi menunjukkan tingkat akurasi menggunakan ekstraksi ciri warna RGB sebesar $80 \%$. Keberhasilan mengidentifikasikan juga dipengaruhi oleh fitur-fitur yang digunakan sebagai penciri pada metode klasifikasi tersebut[11].

Dalam penelitian ini menggunakan fitur ekstraksi untuk mendapatkan karakteristik atau ciri tertentu dari suatu citra digital, Karakteristik yang dimaksud adalah informasi tertentu dari objek (foreground) suatu citra yang membuat suatu citra dapat dibedakan[12]. Pada Fitur Ekstraksi terdiri dari beberapa metode salah satunya adalah Gray Level Co-occurrence Matrix (GLCM), peneliti memilih GLCM karena merupakan metode statistika untuk membentuk fitur/ciri yang tidak didasarkan pada nilai piksel semata dan hubungan ketetanggaan piksel[13], adapun nilai yang dihasilkan pada GLCM itu sendiri berupa Contrast, Correlation, Energy, dan Homogenity. sedangkan Klasifikasi dengan Naive Bayes merupakan klasifikasi berdasar teorema Bayes dengan asumsi antar variabel penjelas independen. Cara ini dapat diasumsikan sebagai keadaan atau ketiadaan dari sebuah kejadian tertentu dari suatu grup yang tidak berhubungan dengan keadaan atau ketiadaan kejadian lain[14].

\section{Metode}

Dalam penelitian ini terdiri dari beberapa tahapan, Tahapan Penelitian tersebut adalah:

A. Pengumpulan Data

Teknik yang dilakukan dalam mengumpulkan data terkait pengelompokkan buah jeruk keprok didapatkan dari hasil pemotretan buah jeruk sebanyak 130 buah jeruk keprok.

\section{B. Pembagian Data Gambar}

Gambar yang telah didapatkan akan pisahkan menjadi 2 bagian yaitu data latih dan data uji, dimana pada data latih terdapat 110 buah jeruk keprok, sedangkan untuk data uji terdapat 20 buah jeruk keprok. 
C. Preprocessing Data

Selanjutnya dilakukan proses untuk mentransformasi warna citra dari berwarna (RGB) menjadi keabuan (grayscale), guna inputan untuk proses selanjutnya.

\section{Fitur Ekstraksi}

Fitur Ekstraksi citra pada buah jeruk keprok bertujuan untuk memperoleh ciri yang terdapat dari citra jeruk keprok yang matang dan yang belum matang yang menggunakan ekstraksi fitur histogram yang menampilkan sebuah hasil berupa angka /numerik. Pada penelitian ini menggunakan empat fitur ekstraksi meliputi: Contrast, Correlation, Energy, dan Homogenity. Berikut Persamaan dari Fitur ekstraksi GLCM[15] :

- Contrast :

Contrast menyatakan kandungan variasi lokal pada citra. Semakin tinggi nilai contrast maka semakin tinggi tingkat kekontrasannya. Nilai Contrast dapat dicari menggunakan persamaan (1).

$$
C 1=\sum i_{i} j|i-j| 2 p\left(i_{i} j\right)
$$

- Correlation :

Correlation menyatakan ukuran hubungan linear dari nilai graylevel piksel ketetanggan. Nilai correlation dapat dicari menggunakan persamaan (2).

$$
C 2=\sum i_{v} j \frac{(1-\mu i)(j-\mu j) P(i, j)}{\sigma i \sigma j}
$$

- Energy:

Energy mengukur tingkat keseragaman piksel-piksel pada suatu citra. Energi mencapai nilai tertinggi saat persebaran level keabuan konstan atau bersifat periodik. Semakin tinggi nilai energy, maka semakin seragam teksturnya. Nilai energy dapat dicari menggunakan persamaan (3).

$$
E 1=\sum i_{i} j P(i, j)^{2}
$$

- Homogenity

Homogeneity menyatakan ukuran kedekatan setiap elemen dari co-occurrence matrix (kehomogenan piksel). Nilainya dapat dicari menggunakan persamaan (4).

$$
H=\sum i, j \frac{P(i, j)}{1+\lceil\mid i, j]}
$$

E. Klasifikasi Nä̈ve Bayes

Setelah nilai-nilai fitur ekstraksi telah didapat. Nilai tersebut akan diklasifikasi dengan Naïve Bayes, sehingga nantinya akan didapatkan hasil klasifikasi berupa jeruk yang matang atau yang belum matang. Dalam pengelompokkan buah jeruk menggunakan Metode Naïve Bayes berdasakan persamaan (5).

$$
P(H \mid X)=\frac{P(X \mid H) P[(H)}{P[X]}
$$

\section{F. Hasil Klasifikasi}

Setalah citra baru yang di uji akan mendapatkan hasil sesuai kategori. Kategori yang dimaksudkan adalah berupa jeruk yang matang atau jeruk yang belum matang.

\section{G. Pengujian Sistem}

Setelah didapatkan hasil klasifikasi yag berdasarkan kategori maka akan di uji keakuratan kematangannya seberapa akurat dengan menggunakan pengukuran Confusion Matrix. Berikut perhitungan akurasi secara matematis ditunjukkan pada persamaan (6)

$$
\text { Accuracy }=\frac{T P+T N}{T P+T N+F P+F N} \times 100 \%
$$

Alir pada tahapan penelitian ini ditunjukkan pada Gambar 1. 


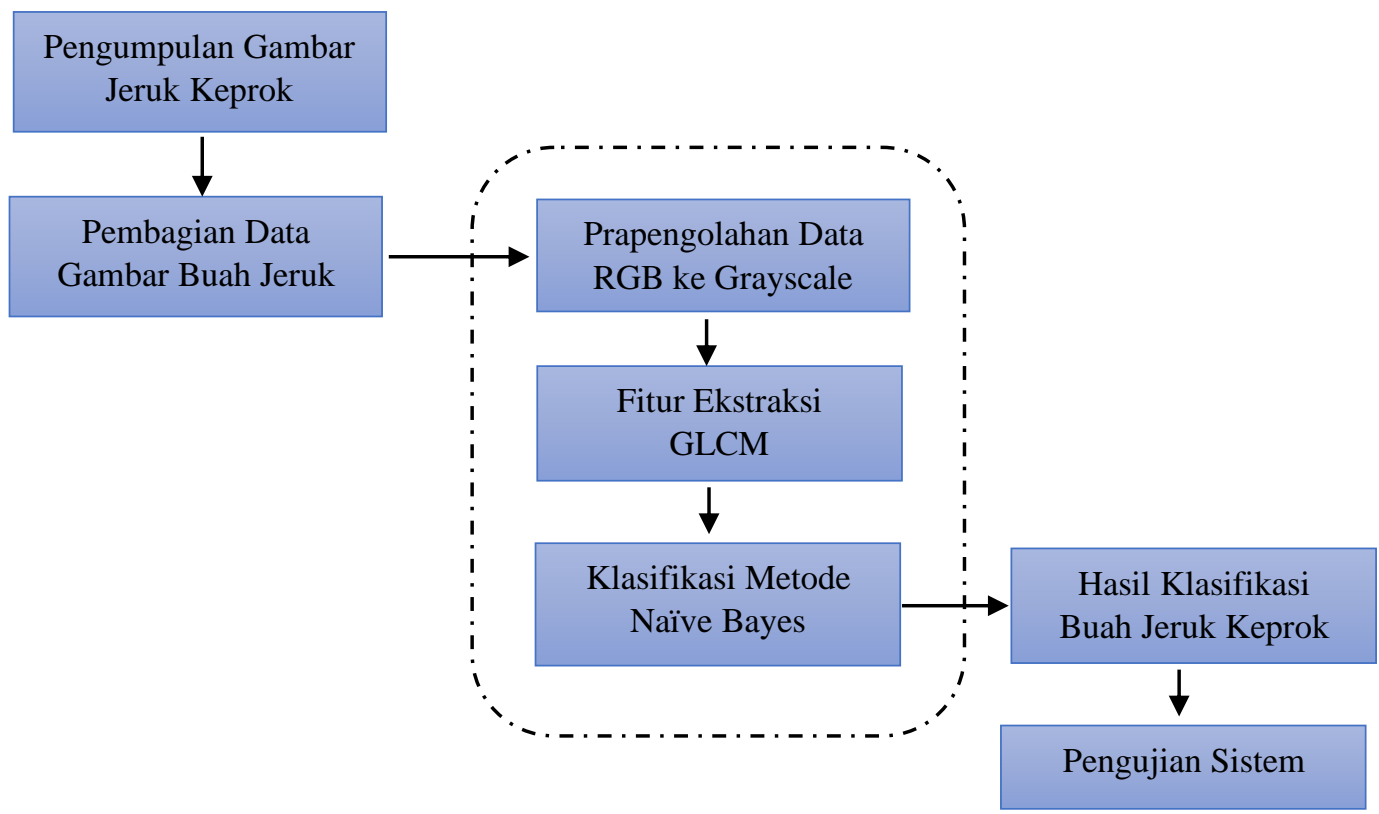

Gambar 1. Alur Tahapan Penelitian

\section{Hasil dan Pembahasan}

A. Pembagian Data Latih Jeruk Keprok

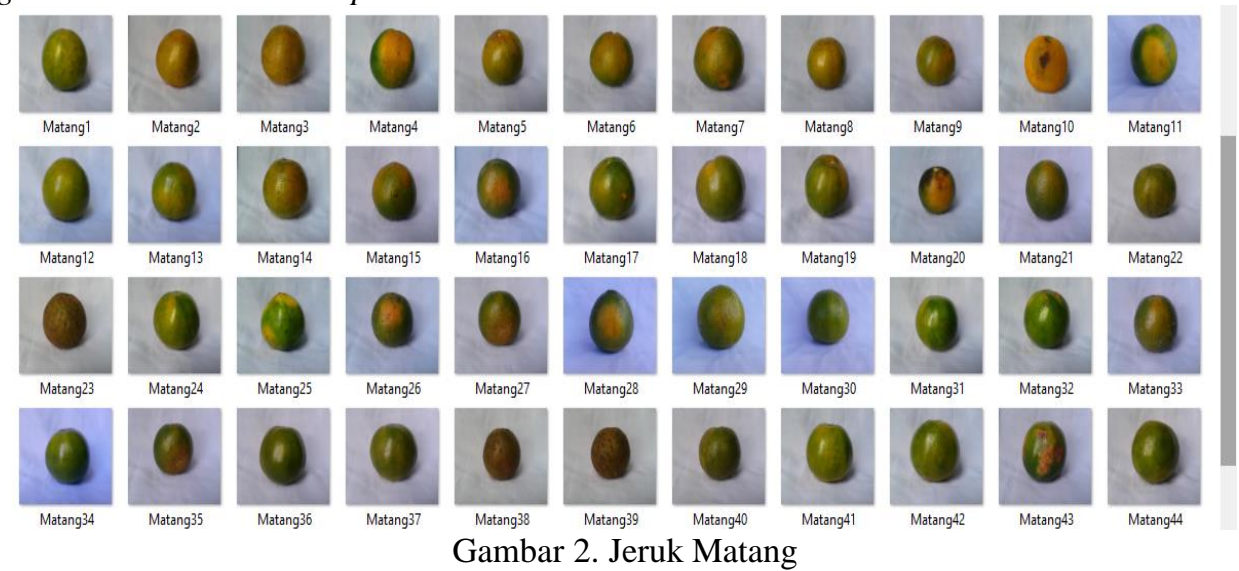

Pada Gambar 2 jeruk matang terdiri dari 65 data gambar yang matang

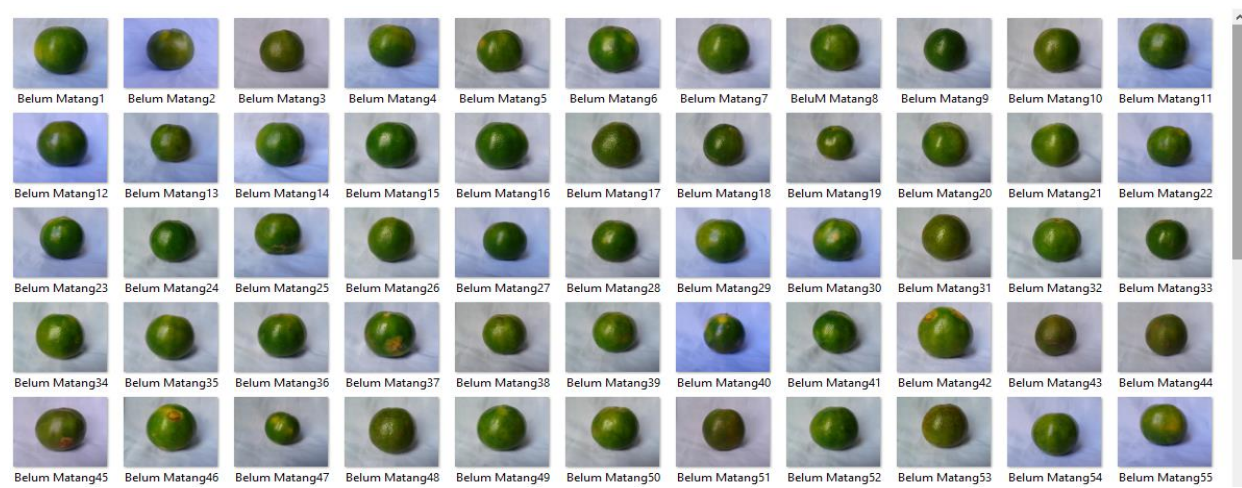

Gambar 3. Jeruk Belum Matang

Pada Gambar 3 jeruk yang belum matang terdiri dari 65 jumlah data gambar jeruk. 


\section{B. Pembagian Data Uji}

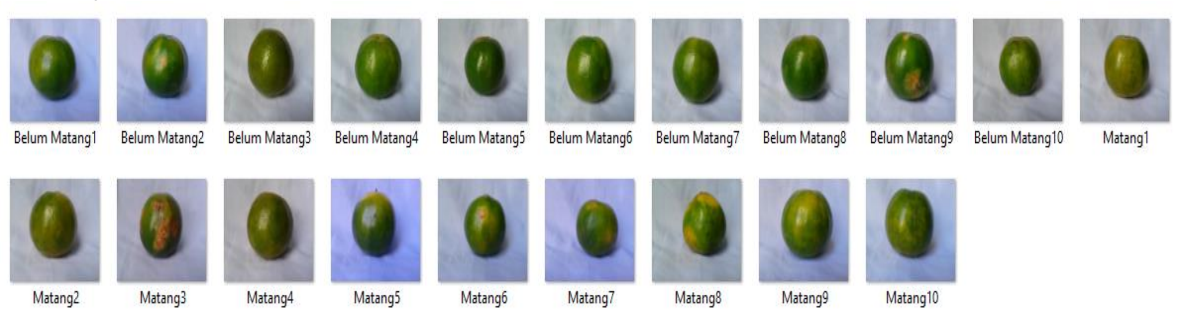

Gambar 4. Data Uji

Gambar 4 menunjukkan data uji citra jeruk keprok dimana terdapat 10 gambar jeruk yang matang dan 10 gambar yang tidak matang.

\section{Preprocessing Gambar}

Setelah Citra dibagi berdasarkan kategori, maka citra dalam bentuk RGB akan di ubah kedalam bentuk citra keabuan (Grayscale) pada tahap ini untuk memudahkan dalam mendapatkan matrix GLCM. Tabel 1 menunjukkan Citra RGB ke Grayscale.

Tabel 1. Citra RGB ke Grayscale

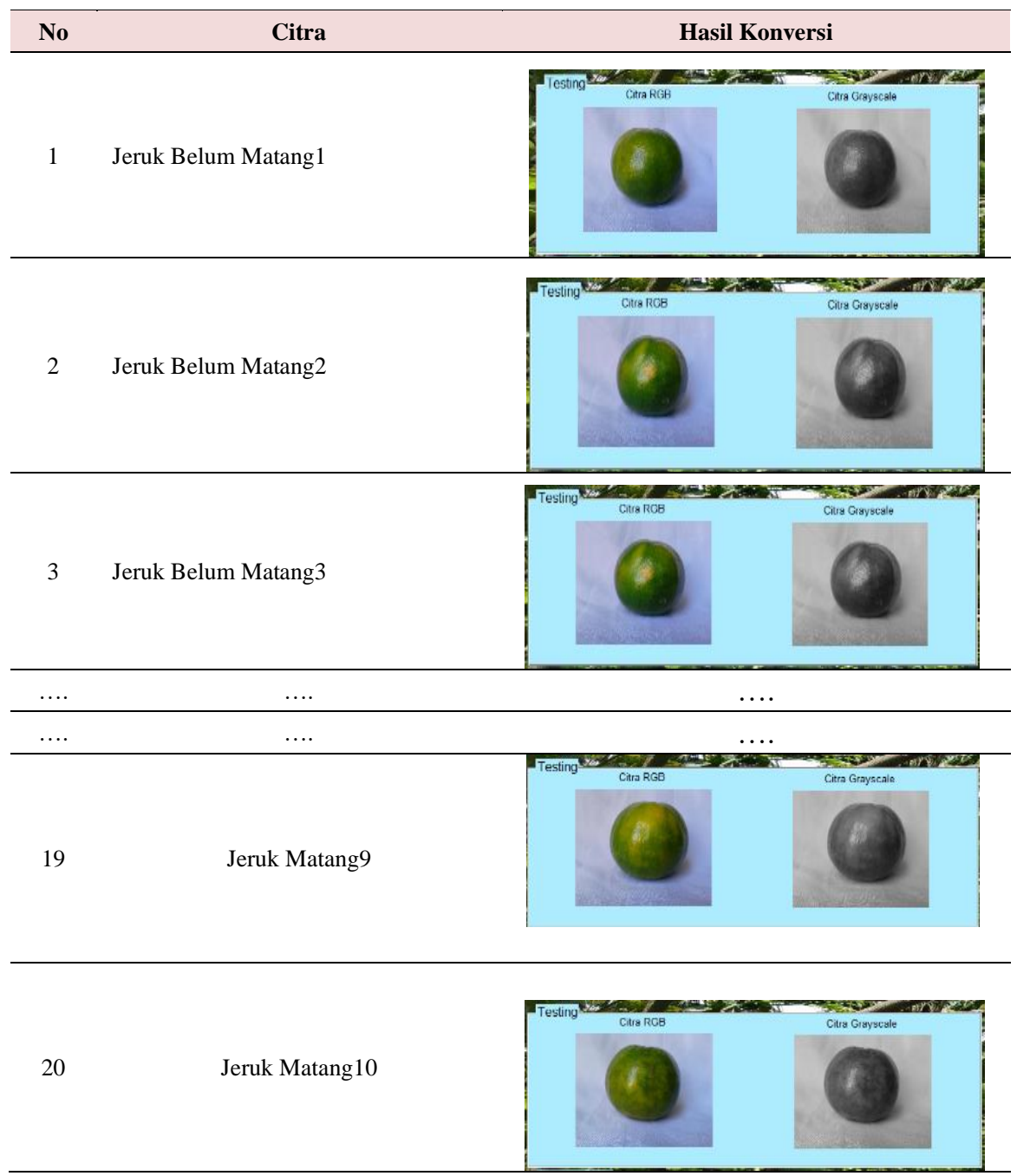

\section{Fitur Ekstraksi GLCM}

Setalah tahapan preprocessing gambar, akan dilakukan proses ekstraksi GLCM, lalu untuk menentukan hasil ekstrasi ciri dengan memperhitungkan nilai Contrast, Correlation, Energy dan 
Homogeneity. Semua data citra akan memiliki nilai ciri yang berbeda, sehingga citra uji akan ditentukan nilai kemiripan dengan citra queri.

Tabel 2. Nilai Matrix GLCM

\begin{tabular}{|c|c|c|c|c|c|}
\hline No & Citra & Nilai Contrast & Nilai Correlation & Nilai Energy & Nilai Homogenity \\
\hline 1 & $\begin{array}{l}\text { Jeruk belum } \\
\text { matang1 }\end{array}$ & 143.538 & 6.97892 & 2487.38 & 0.958776 \\
\hline 2 & $\begin{array}{l}\text { Jeruk belum } \\
\text { matang2 }\end{array}$ & 142.896 & 6.9563 & 2274.96 & 0.989634 \\
\hline 3 & $\begin{array}{l}\text { Jeruk blum } \\
\text { matang3 }\end{array}$ & 137.746 & 6.93055 & 2454.96 & 0.867182 \\
\hline$\ldots$ & $\ldots$. & $\ldots$ & $\ldots$. & $\ldots$ & $\cdots$ \\
\hline$\ldots$ & $\ldots$ & $\ldots$ & $\ldots$. & $\ldots$ & $\cdots$ \\
\hline 19 & $\begin{array}{l}\text { Jeruk } \\
\text { matang9 } \\
\end{array}$ & 139.891 & 6.99141 & 2123.49 & 0.763208 \\
\hline$\ldots$ & $\ldots$ & $\ldots$ & $\ldots$ & $\ldots$ & \\
\hline 20 & $\begin{array}{l}\text { Jeruk } \\
\text { matang10 }\end{array}$ & 142.008 & 7.03084 & 2372.75 & 0.790468 \\
\hline
\end{tabular}

Dari nilai pada Tabel 2 tersebut merupakan hasil dari proses ekstraksi GLCM. Dari hasil inilah yang akan digunakan untuk melakukan klasifikasi dengan menggunakan metode Naïve Bayes.

\section{E. Klasifikasi Nä̈ve Bayes}

Hasil klasifikasi data citra uji menggunakan probabilstik pada metode nä̈ve bayes terhadap kemiripan data uji terhadap data latih. Hasil akhirnya adalah nilai probabilistik dari data citra uji dengan ketentuan kategorinya. Kategori yang dimaksudkan adalah kategori berupa jeruk yang matang dengan jeruk yang tidak matang.

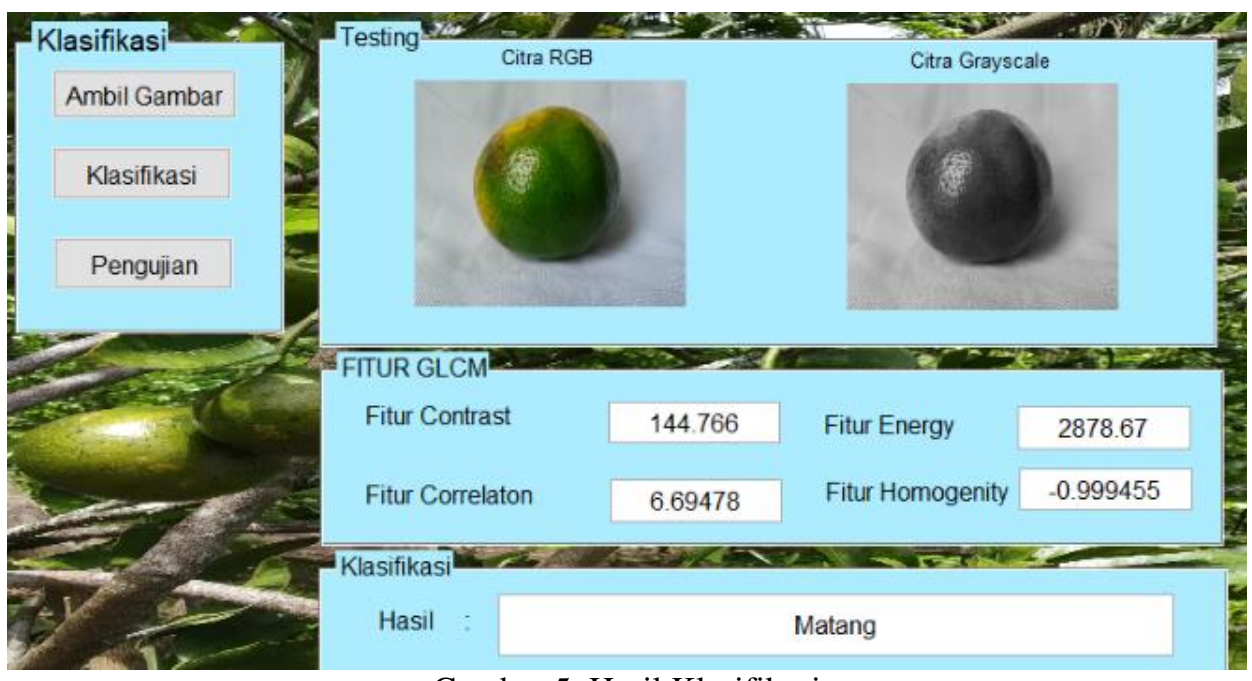

Gambar 5. Hasil Klasifikasi

Berdasarkan pada hasil penelitian bahwa dengan adanya sistem pengelompokkan ini Dapat melakukan pengklasifikasian kematangan buah jeruk keprok dengan menggunakan fiur ekstraksi GLCM dan metode Naïve Bayes serta Dapat memperoleh kinerja yang efektif dan efisien dari sistem klasifikasi kematangan buah jeruk keprok sehingga dapat di implementasikan.

\section{F. Pengujian Sistem}

Dalam Penelitian ini tahap pengujian dilakukan dengan menggunakan Confusion Matrix, hasil yang diperoleh dari hasil klasifikasi yang telah didapatkan matang sebesar $82 \%$

Accuracy $=\frac{T P+T N}{T P+T N+F P+F N} \times 100 \%=82 \%$.

Gambar 6 Menunjukkan Hasil pengujian yang dilakukan pada sistem yang bangun. 


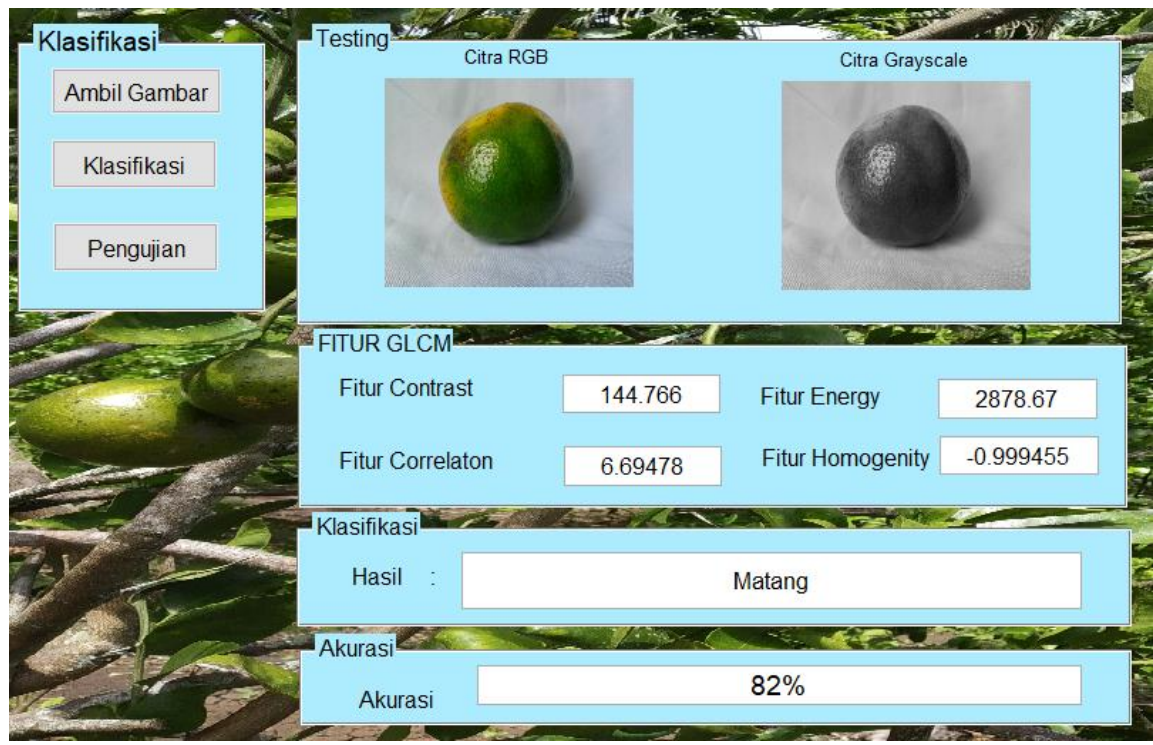

Gambar 6. Hasil Pengujian

\section{Kesimpulan dan saran}

Berdasarkan hasil yang telah dilakukan, bahwa dengan sistem menggunakan metode Nä̈ve Bayes pada citra jeruk keprok dapat diklasifikasikan dan memperoleh kinerja yang efektif dan efisien berdasarkan pengujian sebesar $82 \%$ sehingga dapat di implementasikan. Adapun Saran pada penelitian ini yaitu pada peneliti yang ingin mengembangkan sistem cerdas ini diharapkan dengan adanya penambahan fitur berupa LBP yang bisa dipadukan nantinya dengan GLCM, serta data yang akan digunakan pada peneliti selanjutnya di tambahkan lebih banyak lagi dari peneliti sebelumnya.

\section{Daftar Pustaka}

[1] H. Prabowo, "Deteksi Kondisi Kematangan Buah Jeruk Berdasarkan Kemiripan Warna Pada Ruang Warna Rgb Berbasis Android," vol. 3, no. 2, 2017.

[2] M. Widyaningsih, "Identifikasi Kematangan Buah Apel Dengan Gray Level Co-Occurrence Matrix (GLCM)," J. SAINTEKOM, vol. 6, no. 1, p. 71, 2017, doi: 10.33020/saintekom.v6i1.7.

[3] U. E. Mas'ud Effendi, Fitriyah, "Identifikasi Jenis Dan Mutu Teh Menggunakan Pengolahan Citra Digital," J. Teknotan, vol. 11, no. 2, pp. 67-76, 2017.

[4] Yuda Permadi and Murinto, "Buah Menggunakan Metode Ekstraksi Ciri Statistik," J. Inform., vol. 9, no. 1, pp. 1028-1038, 2015.

[5] A. R. Putri, "Pengolahan Citra Dengan Menggunakan Web Cam Pada Kendaraan Bergerak Di Jalan Raya," JIPI (Jurnal Ilm. Penelit. dan Pembelajaran Inform., vol. 1, no. 01, pp. 1-6, 2016, doi: 10.29100/jipi.v1i01.18.

[6] E. K. Ratnasari and A. Wikaningrum, "Pengenalan Jenis Buah pada Citra Menggunakan Pendekatan Klasifikasi Berdasarkan Fitur Warna Lab dan Tekstur Co- Occurrence,” J. Inf., vol. 1, no. 2, pp. 8897, 2016.

[7] A. Ciputra, A. Susanto, and dkk, "Dengan Algoritma Naive Bayes Dan Ekstraksi Fitur Citra Digital," Simetris J. Tek. Mesin, Elektro dan Ilmu Komput., vol. 9, no. 1, pp. 465-472, 2018.

[8] R. A. Asmara, B. S. Andjani, U. D. Rosiani, and P. Choirina, "Klasifikasi Jenis Kelamin Pada Citra Wajah Menggunakan Metode Naive Bayes," J. Inform. Polinema, vol. 4, no. 3, p. 212, 2018, doi: 10.33795/jip.v4i3.209.

[9] I. G. S. Rahayuda, "Identifikasi Jenis Obat Berdasarkan Gambar Logo Pada Kemasan Menggunakan Metode Naive Bayes," Sisfo, vol. 06, no. 01, pp. 17-36, 2016, doi: 10.24089/j.sisfo.2016.09.002.

[10] Y. P. Journal, R. A. Syifa, K. Adi, D. Fisika, and U. Diponegoro, "Analisis Tekstur Citra Mikroskopis Kanker Paru Menggunakan Metode Gray Level Co-Occurance Matrix (Glcm) Dan Tranformasi Wavelet Dengan Klasifikasi Naive Bayes,” Youngster Phys. J., vol. 5, no. 4, pp. 457462, 2016.

[11] F. Y. Manik and K. S. Saragih, "Klasifikasi Belimbing Menggunakan Naïve Bayes Berdasarkan Fitur Warna RGB," IJCCS (Indonesian J. Comput. Cybern. Syst., vol. 11, no. 1, p. 99, 2017, doi: 10.22146/ijccs. 17838 .

[12] K. Auliasari and M. Kertaningtyas, "Studi Komparasi Klasifikasi Pola Tekstur Citra Digital Menggunakan Metode K-Means Dan Naïve Bayes,” J. Inform., vol. 18, no. 2, pp. 1-11, 2018. 
[13] S. M. Treatment et al., "Klasifikasi Buah Jeruk Menggunakan Metode Naive Bayes Berdasarkan Analisis Tekstur dan Normalisasi Warna," vol. 1, no. 1, pp. 2374-2376, 2016.

[14] K. Prajatama, F. E. Nugroho, A. F. Sentosa, and S. Fauziah, "Deteksi Kualitas Buah Apel Malang Manalagi Menggunakan Algoritma Naive Bayes Quality Detection Of Malang Manalagi Apple Fruit Using The Algorithm Naive Bayes Program Studi S1 Jurusan Informatika Fakultas Ilmu Komputer Universitas Pengambilan Data Ekstraks,” vol. 8, no. 1, pp. 32-38, 2019.

[15] A. Septiarini and R. Wardoyo, "Kompleksitas Algoritma GLCM untuk Ekstraksi Ciri Tekstur pada Penyakit Glaucoma,” no. April, pp. 98-102, 2016. 